\title{
Recovery of Cobalt and Manganese from Spent Lithium-ion Batteries using a Phosphonium-based Ionic Liquid
}

\author{
Mochmad L. FIRMANSYAH ${ }^{1, *}$, Adroit T. N. FAJAR ${ }^{2}$, Rino R. MUKTI ${ }^{3,4,5}$, Thalabul ILMI ${ }^{3}$, \\ Grandprix T. M. KADJA ${ }^{3,4,6}$ and Masahiro GOTO ${ }^{2, *}$ \\ ${ }^{1}$ Nanotechnology Engineering, School of Advanced Science and Multidisciplinary, Airlangga University, Jl. \\ Dr. Ir. H. Soekarno, Surabaya 60115, Indonesia; ${ }^{2}$ Department of Applied Chemistry, Graduate School of \\ Engineering, Kyushu University, 744 Motooka, Fukuoka 819-0395, Japan; ${ }^{3}$ Division of Inorganic and \\ Physical Chemistry, Faculty of Mathematics and Natural Science, Institut Teknologi Bandung, Jl Ganesha \\ 10, Bandung 40132, Indonesia; ${ }^{4}$ Research Center for Nanoscience and Nanotechnology, Institut Teknologi \\ Bandung, Jl Ganesha 10, Bandung 40132, Indonesia; ${ }^{5}$ Research and Innovation Center for Advanced \\ Materials, Institut Teknologi Sumatera, Jl. Terusan Ryacudu, Lampung 35365, Indonesia; ${ }^{6}$ Center for \\ Catalysis and Reaction Engineering, Institut Teknologi Bandung, Jalan Ganesha no. 10, Bandung, 40132, \\ Indonesia.
}

(Received August 25, 2020; Accepted October 1, 2020)

A novel ionic liquid (IL) trioctyldodecyl phosphonium bis(2,4,4-trimethylpentyl)phosphinate was developed as a recovery agent for cobalt(II) and manganese(II) from spent lithium-ion batteries (LIBs). Absence of organic diluent provides an advantageous factor to IL-based extraction than the conventional one. $\mathrm{Co}(\mathrm{II})$ and $\mathrm{Mn}(\mathrm{II})$ were extracted quantitatively from the aqueous phase to the IL phase. Extracted $\mathrm{Co}(\mathrm{II})$ and $\mathrm{Mn}$ (II) were stripped from the IL using water and $\mathrm{NH}_{4} \mathrm{NO}_{3}$, respectively. After stripping, the IL can be reused as the extractant, facilitating the realization of a continuous extraction process. The developed hydrophobic IL shows promise as an extractant for $\mathrm{Co}(\mathrm{II})$ and $\mathrm{Mn}$ (II) from the spent LIBs.

\section{Introduction}

Lithium-ion batteries (LIBs) have become crucial components of many modern technologies. LIBs are attractive for power storage because of their high charge density, which allows them to be more compact than other rechargeable batteries [1]. The increased use of various types of portable equipment, such as mobile devices and personal computers, in recent decades, has led to huge growth in their market and greatly stimulated the production of LIBs. However, the great increase of LIB usage will be followed by the problem of spent LIBs in forthcoming years [2]. The cathodes of LIBs contain various valuable metals, such as lithium (Li), cobalt (Co), nickel (Ni), and manganese (Mn). Therefore, recycling spent LIBs is considered beneficial from both economic and environmental aspects. To date, the approaches used to recycle valuable metals in LIBs mainly involve pyrometallurgical and hydrometallurgical processes [3]. Liquid-liquid extraction is an important hydrometallurgical method in metal processing. For spent LIBs, liquid-liquid extraction is generally carried out using an inorganic acid, such as $\mathrm{H}_{2} \mathrm{SO}_{4}, \mathrm{HCl}$, or $\mathrm{HNO}_{3}$, as an acidic leaching agent [4]. 
Extracting agents, such as bis(2,4,4-trimethylpentyl)phosphinic acid (Cyanex 272) [5], di-(2-ethylhexyl)phosphoric acid (D2EHPA) [5], bis(2,4,4-trimethylpentyl)dithiophosphinic acid (Cyanex 301) [6], 2-ethylhexylphosphonic mono-2-ethylhexyl ester [7], and $N, N$-dioctyl-1-octanamine (Alamine 336) [6] have been widely used to recover Co and Mn from not only primary ores but also secondary sources; e.g., spent LIBs. However, these conventional extractants require a large amount of solvent, such as toluene or kerosene, as a diluent. Those solvents are classified as volatile organic compounds, which have limited reusability and raise environmental concerns because of their high vapor pressure, flammability, and toxicity. Thus it is beneficial not only from economical but also from environmental viewpoint to find a suitable replacement for those solvents.

A possible alternative to organic solvents is ionic liquids (ILs). Over the past few years, ILs have been explored as a possible alternative to organic solvents and extractive agents, due to their low vapor pressure and adjustable properties. In 2012, Rybka and colleagues used phosphonium-based ILs to separate $\mathrm{Co}(\mathrm{II})$ from $\mathrm{Ni}(\mathrm{II})$ [8]. However, toluene was required as a diluent for the IL. Wellens et al. reported the first example of $\mathrm{Co}(\mathrm{II})$ extraction using undiluted trihexyltetradecylphosphonium chloride $\left(\mathrm{P}_{6,6,6,14} \mathrm{Cl}\right)$ [9] . They found that the undiluted system provided better separation factors for Co(II) from other metals compared with those of diluted systems. Recently, trioctyl(alkyl)phosphonium chloride ILs diluted with toluene have been used for Co(II) extraction [10]. They achieved excellent Co(II) extraction performance at high $\mathrm{HCl}$ concentration. Only a few examples of $\mathrm{Mn}$ (II) extraction using ILs have been reported. Ola et al., used trihexyltetradecylphosphonium bromide $\left(\mathrm{P}_{6,6,6,14} \mathrm{Br}\right), \mathrm{P}_{6,6,6,14} \mathrm{Cl}$, and Alamine 336 to extract and separate $\mathrm{Mn}(\mathrm{II})$ from Fe(III) [12,13]. Several conventional extractants, such as D2EHPA, Cyanex 272, and Cyanex 301 have shown excellent performance in recovering valuable metals from spent-LIBs [13,14]. However, the use of undiluted ILs to recover valuable metals from spent LIBs has seldom been explored.

Trihexyltetradecylphosphonium bis(2,4-trimethylpentyl)phosphinate $\left(\mathrm{P}_{6,6,614} \mathrm{R}_{2} \mathrm{POO}\right)$ has been investigated as an extractant for several kinds of metals. $\mathrm{P}_{6,6,6,14} \mathrm{R}_{2} \mathrm{POO}$ has also been explored as an extraction agent for $\mathrm{Co}(\mathrm{II})[9,12,17]$. Bradaric et al. reported the synthesis and characterization of $\mathrm{P}_{6,6,6,14} \mathrm{R}_{2} \mathrm{POO}$ [15]. Rybka et al. achieved a good separation factor of $\mathrm{Co}(\mathrm{II})$ from $\mathrm{Ni}(\mathrm{II})$ in chloride media using $\mathrm{P}_{6,6,6,14} \mathrm{R}_{2} \mathrm{POO}$ [8]. Moreover, $\mathrm{P}_{6,6,6,14} \mathrm{R}_{2} \mathrm{POO}$ can also be used simultaneously with other immiscible ILs, such as imidazolium-based ILs. For example, a combination of $\mathrm{P}_{6,6,6,14} \mathrm{R}_{2} \mathrm{POO}$ and 1-ethyl-methylimidazolium chloride was able to extract $\mathrm{Co}(\mathrm{II})$ from $\mathrm{Ni}(\mathrm{II})$ with a high separation factor [13]. Previously, we synthesized trioctyldodecylphosphonium halides $\left(\mathrm{P}_{8,8,8,12} \mathrm{X} ; \mathrm{X}=\mathrm{Cl}, \mathrm{Br}\right)$, which were used as extractants for valuable metals $[19,20]$. These ILs showed higher hydrophobicity and lower viscosity than those of their commercial counterparts. Combining the trioctyldodecylphosphonium cation $\left(\mathrm{P}_{8,8,8,12}{ }^{+}\right)$and bis $\left(2,4,4\right.$-trimethylpentyl)phosphinate anion $\left(\mathrm{R}_{2} \mathrm{POO}^{-}\right)$could yield ILs with greatly enhanced performance in the recovery of valuable metals. Moreover, few studies on the extraction and separation of valuable metals from spent LIBs using phosphonium-based ILs with $\mathrm{R}_{2} \mathrm{POO}^{-}$have been reported. In this study, the phosphonium-based IL trioctyldodecylphosphonium bis(2,4,4-trimethylpentyl)phosphinate $\left(\mathrm{P}_{8,8,8,12} \mathrm{R}_{2} \mathrm{POO}\right)$ is synthesized and used as an extractant to recover valuable metals from the leachate of spent LIBs. 


\section{Experimental}

\subsection{Reagents}

Trioctylphosphine (97\%) and 1-chlorododecane (97\%), which were used as precursors for trioctyldodecylphosphonium chloride $\left(\mathrm{P}_{8,8,8,12} \mathrm{Cl}\right)$, were obtained from Sigma Aldrich (Tokyo, Japan) and Tokyo Chemical Industry Co., Ltd (Tokyo, Japan), respectively. Bis(2,4,4-trimethylpentyl)phosphinic acid (92\%), which is one of the precursors of $\mathrm{P}_{6,6,6,14} \mathrm{R}_{2} \mathrm{POO}$ was purchased from Sigma Aldrich (Tokyo, Japan). Nitric acid $\left(5 \mathrm{~mol} \mathrm{~L}^{-1}\right), \mathrm{HCl}\left(5 \mathrm{~mol} \mathrm{~L}^{-1}\right), \mathrm{H}_{2} \mathrm{SO}_{4}\left(5 \mathrm{~mol} \mathrm{~L}^{-1}\right)$, anhydrous $\mathrm{Na}_{2} \mathrm{SO}_{4}(99.9 \%), \mathrm{NH}_{4} \mathrm{NO}_{3}(98.0 \%)$, anhydrous $\mathrm{FeCl}_{3}(99.0 \%), \mathrm{CoCl}_{2} .5 \mathrm{H}_{2} \mathrm{O}(99.0 \%), \mathrm{CuCl}_{2} .2 \mathrm{H}_{2} \mathrm{O}(99.9 \%)$, and $\mathrm{MnCl}_{2} .4 \mathrm{H}_{2} \mathrm{O}$ (99.0\%) were purchased from Wako Pure Chemical Ltd (Osaka, Japan). $\left(\mathrm{NH}_{4}\right)_{2} \mathrm{FeSO}_{4} \cdot 6 \mathrm{H}_{2} \mathrm{O}(98 \%), \mathrm{NH}_{3} \mathrm{OHCl}(96 \%)$, formaldehyde solution, hexamethylenetetramine (99.0\%), ethylenediamine tetraacetate (EDTA, 98.0\%), xylenol orange disodium salt, $\mathrm{Na}_{2} \mathrm{SO}_{3}(98.0 \%)$, and $\mathrm{NiCl}_{2} .6 \mathrm{H}_{2} \mathrm{O}(99.9 \%)$ were purchased from Sigma Aldrich (Singapore).

\subsection{Synthesis of trioctyldodecylphosphonium chloride $\left(\mathbf{P}_{\mathbf{8}, 8,8,12} \mathrm{Cl}\right)$}

$\mathrm{P}_{8,8,8,12} \mathrm{Cl}$ (Figure 1a) was synthesized using a similar procedure to that described previously [17]. The synthesis process was done under nitrogen atmosphere. Chlorododecane $(0.11 \mathrm{~mol} \mathrm{eq}$.) was placed into a $50 \mathrm{~cm}^{3}$ three-neck round-bottom flask with a stirring bar. Trioctylphosphine $(0.1 \mathrm{~mol}$ eq. $)$ was added slowly to the flask and then the flask was flushed again with nitrogen before being sealed. The synthesis was carried out at $145^{\circ} \mathrm{C}$ for $16 \mathrm{~h}$ in an oil bath. To remove the excess 1-chlorododecane, the final product was dissolved in hexane, and then extracted with water. The final product was dried using an evaporator (EYELA N-1000, Tokyo, Japan) at $40^{\circ} \mathrm{C}$ in vacuo for $3 \mathrm{~h} . \mathrm{P}_{8,8,8,12} \mathrm{Cl}$ was obtained as a clear liquid with 98\% yield (by mass) and its purity exceeded $96.0 \%$.

$\mathrm{P}_{8,8,8,12} \mathrm{Cl}$ was characterized by ${ }^{1} \mathrm{H},{ }^{13} \mathrm{C}$, and ${ }^{31} \mathrm{P}$ NMR spectroscopy (Bruker Bio Spin AVANCE500, Kanagawa, Japan) and elemental analysis (Yanaco CHN Corder MT-5, Kyoto, Japan). ${ }^{1} \mathrm{H}$ NMR (400.13 $\mathrm{MHz}$ in $\left.\mathrm{CDCl}_{3}\right): \delta 2.49-2.62\left(8 \mathrm{H}, \mathrm{RCH}_{2} \mathrm{P}\right), 1.60-1.70\left(8 \mathrm{H}, \mathrm{RCH}_{2} \mathrm{CH}_{2} \mathrm{P}\right), 1.48-1.54\left(8 \mathrm{H}, \mathrm{RCH}_{2} \mathrm{CH}_{2} \mathrm{CH}_{2} \mathrm{P}\right)$, $1.25-1.45\left(40 \mathrm{H}, \mathrm{RCH}_{2} \mathrm{R}\right), 0.88\left(12 \mathrm{H}, \mathrm{CH}_{3} \mathrm{CH}_{2} \mathrm{R}\right) .{ }^{13} \mathrm{C} \mathrm{NMR}\left(100.54 \mathrm{MHz}\right.$ in $\left.\mathrm{CDCl}_{3}\right): \delta 33.02,31.89,30.76$, 30.33, 23.68, 22.77, 19.38, 14.61. ${ }^{31} \mathrm{P}$ NMR (161.90 MHz in $\left.\mathrm{CDCl}_{3}\right): \delta 34.20$. Anal. Calcd for $\mathrm{C}_{36} \mathrm{H}_{76} \mathrm{PCl}$ : C, 74.98; H, 13.46, N, 0.00. Found: C, 74.66; H, 13.41; N, 0.01.

\subsection{Synthesis of trioctyldodecylphosphonium bis(2,4,4-trimethyl pentyl)phosphinate $\left(\mathbf{P}_{8,8,8,12} \mathbf{R}_{2} \mathbf{P O O}\right)$}

$\mathrm{P}_{8,8,8,12} \mathrm{R}_{2} \mathrm{POO}$ (Figure 1b) was synthesized by anionic exchange between $\mathrm{P}_{8,8,8,12} \mathrm{Cl}$ and bis(2,4,4-trimethylpentyl)phosphinic acid following the method reported by Dharaskar et al. [18]. Bis(2,4,4-trimethylpentyl)phosphinic acid $(4.760 \mathrm{~g}, 0.01635 \mathrm{~mol})$ was mixed with $\mathrm{P}_{8,8,8,12} \mathrm{Cl}(9.216 \mathrm{~g}$, $0.1635 \mathrm{~mol})$ in hexane $(15 \mathrm{~g})$. Then, a $\mathrm{NaOH}$ solution $\left(9 \mathrm{~mol} \mathrm{~L}^{-1}\right)$ was slowly added to the mixture and stirred at room temperature for $4 \mathrm{~h}$. The organic phase was then separated and washed with water several times. The residue of the aqueous phase was further removed by using anhydrous $\mathrm{Na}_{2} \mathrm{SO}_{4}$. The solvent was evaporated by a rotary evaporator (EYELA N-1000, Tokyo, Japan) for $3 \mathrm{~h}$ at $40^{\circ} \mathrm{C}$. The yield of $\mathrm{P}_{8,8,8,12} \mathrm{R}_{2} \mathrm{POO}$ was $95 \%$ (by mass).

$\mathrm{P}_{8,8,8,12} \mathrm{R}_{2} \mathrm{POO}$ was characterized by ${ }^{1} \mathrm{H},{ }^{13} \mathrm{C}$, and ${ }^{31} \mathrm{P}$ NMR spectroscopy (Agilent DD2, Singapore) and elemental analysis (Yanaco CHN Corder MT-5, Kyoto, Japan). ${ }^{1} \mathrm{H}$ NMR (500.13 $\mathrm{MHz}$ in $\mathrm{CDCl}_{3}$ ): $\delta$ 2.49-2.62 (8H, RCH $\left.\mathrm{R}_{2} \mathrm{P}\right), 1.70-1.40\left(16 \mathrm{H}, \mathrm{RCH}_{2} \mathrm{CH}_{2} \mathrm{P} ; 4 \mathrm{H},\left(\mathrm{RCH}_{2}\right)_{2} \mathrm{PO}_{2}\right), 1.25-0.90\left(40 \mathrm{H}, \mathrm{RCH}_{2} \mathrm{R} ; 6 \mathrm{H}\right.$, $\left.\mathrm{PO}_{2} \mathrm{RCH}_{3} ; 2 \mathrm{H}, \mathrm{PO}_{2} \mathrm{R}_{3} \mathrm{CH} ; 22 \mathrm{H}, \mathrm{PO}_{2} \mathrm{RCH}\left(\mathrm{CH}_{3}\right)_{3}\right), 0.88\left(12 \mathrm{H}, \mathrm{CH}_{3} \mathrm{CH}_{2} \mathrm{R}\right) .{ }^{13} \mathrm{C}$ NMR $(125.4 \mathrm{MHz}$ in 
$\mathrm{CDCl}_{3}$ ): $\delta 13.538-55.127$ (various singlets). ${ }^{31} \mathrm{P} \mathrm{NMR}\left(121.49 \mathrm{MHz}\right.$ in $\left.\mathrm{CDCl}_{3}\right): \delta 33.68$ (s), 34.56 (s). Anal. Calcd for $\mathrm{C}_{52} \mathrm{H}_{110} \mathrm{O}_{2} \mathrm{P}_{2}$ : C, 75.30; H, 13.37, N, 0.00. Found: C, 75.01; H, 13.34; N, 0.00 .

Cation

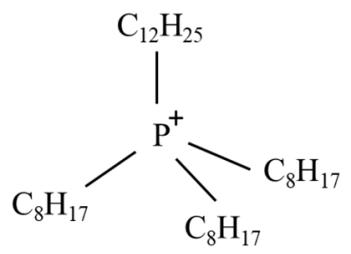

Anion

(a)

(b)

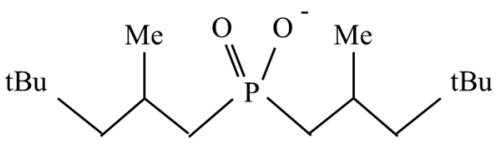

Figure 1. Structures of (a) $\mathrm{P}_{8,8,8,12} \mathrm{Cl}$ and (b) $\mathrm{P}_{8,8,8,12} \mathrm{R}_{2} \mathrm{POO}$.

\subsection{Leaching metals from spent LIBs}

A spent LIB was obtained in fine powder form with a particle size of less than $75 \mu \mathrm{m}$. Initial leaching was conducted by mixing $5 \mathrm{~g}$ spent LIB powder with $5 \mathrm{~mol} \mathrm{~L}^{-1} \mathrm{HCl}$ solution $(50 \mathrm{~mL})$ in a round-bottom flask for a given time in a water bath $\left(25^{\circ} \mathrm{C}\right)$. The mixture was then filtered and the metal concentration was measured by an atomic absorption spectroscopy (AAS).

\subsection{Spectrophotometric determination of metals}

Spectrophotometric determination of $\mathrm{Co}$ (II) and $\mathrm{Ni}(\mathrm{II})$ was performed by EDTA titration following the approach reported by Liu et al. [19]. Initially, a solution containing $100 \mathrm{ppm}$ of either $\mathrm{Co}$ (II) or $\mathrm{Ni}$ (II) in $\mathrm{HCl}$ solution $\left(5 \mathrm{~mol} \mathrm{~L}^{-1}\right)$ was prepared. In $\mathrm{Ni}$ (II) detection with EDTA, 20\% hexamethylenetetramine (10 $\mathrm{mL})$ and water at $70^{\circ} \mathrm{C}(50 \mathrm{~mL})$ were added to the $\mathrm{Ni}(\mathrm{II})$-containing solution to accelerate the complexation reaction of $\mathrm{Ni}(\mathrm{II})$ and EDTA. Then, both $\mathrm{Co}(\mathrm{II})$ - and $\mathrm{Ni}$ (II)-containing solutions were mixed with several drops of xylenol orange disodium salt indicator $\left(5 \mathrm{~g} \mathrm{~L}^{-1}\right)$. Titration was conducted by the addition of 0.01 mol L ${ }^{-1}$ EDTA until the solution changed to purplish red. The solution was heated to boiling. After adding $0.01 \mathrm{~mol} \mathrm{~L}^{-1}$ EDTA, titration was continued until the solution turned bright yellow. The end point was achieved when the color did not change within $30 \mathrm{~s}$.

Determination of $\mathrm{Mn}$ (II) was conducted using formaldoxime as the indicator, as reported by Mirea et al. [20]. $\mathrm{NH}_{3} \mathrm{OHCl}(10 \mathrm{~g})$ was dissolved in distilled water and then mixed with $35 \%$ formaldehyde solution (5 mL). A solution containing $\mathrm{Mn}(\mathrm{II})$ was mixed with $500 \mathrm{mg} \mathrm{L}^{-1}\left(\mathrm{NH}_{4}\right)_{2} \mathrm{Fe}\left(\mathrm{SO}_{4}\right)_{2} \cdot 6 \mathrm{H}_{2} \mathrm{O}$ solution $(1 \mathrm{~mL})$ and EDTA $(2 \mathrm{~mL})$. Formaldoxime solution $(1 \mathrm{~mL})$ and $4 \mathrm{~mol} \mathrm{~L}^{-1} \mathrm{NaOH}$ solution $(2 \mathrm{~mL})$ were added. The solutions were mixed, rested for $10 \mathrm{~min}$, and then $5 \mathrm{~mol} \mathrm{~L}^{-1} \mathrm{NH}_{4} \mathrm{Cl}(3 \mathrm{~mL})$ was added. The solution was left to stand for $1 \mathrm{~h}$ for color development.

The other candidate extractable metals from spent LIB leachate are $\mathrm{Fe}(\mathrm{III})$ and $\mathrm{Cu}(\mathrm{II})$. The spectroscopic determination of these metals was conducted by diluting $\mathrm{CuCl}_{2}$ and $\mathrm{FeCl}_{3}$ solutions to desired concentrations. Then, ultraviolet-visible (UV-vis) spectroscopic analysis was performed at 265 and $340 \mathrm{~nm}$, respectively. All experiments and spectrophotometric measurements were conducted in triplicate to minimize the error, which did not exceed $4 \%$. Spectrophotometric analysis was performed with a Jenway 7615 UV-vis split-beam enabled spectrophotometer (Cole-Parmer Co. Ltd., Birmingham, UK). The absorbance of the solutions was measured using $1 \mathrm{~cm}$-thick quartz cell against double-distilled water as the blank, unless stated otherwise. 


\subsection{Calibration curve}

Different volumes of metal-containing solutions and color-developing reagents were placed in volumetric flasks to obtain different concentrations of the metal in the range of $50-150 \mathrm{mg} \mathrm{L}^{-1}$. The absorbance of each metal-containing solution within the range of $200-800 \mathrm{~nm}$ was measured and then a calibration curve was drawn.

\subsection{Extraction procedure}

The extraction operation was conducted in a similar manner to our previous report [21]. Undiluted IL was mixed with an aqueous metal solution (single metal solution/leachate). The mixture was agitated and shaken in a water bath at $25^{\circ} \mathrm{C}$ for a period of time. Stripping experiment was carried out in a similar manner of the forward extraction experiment. The metal concentrations in the single metal solution were measured by a spectrophotometric method. The metal concentration of the leachate was analyzed with an atomic absorption spectrometer (Agilent Atomic Absorption Systems 280FS AA, Singapore). All experiments were performed with a phase volume ratio of the aqueous phase to the IL of 2:1, unless otherwise stated. The degrees of extraction E (\%) and stripping S (\%) were calculated using Eqs. (1) and (2), respectively,

$$
\begin{aligned}
& \mathrm{E}=\frac{\mathrm{M}_{\mathrm{IL}} \mathrm{V}_{\mathrm{IL}}}{\mathrm{M}_{\mathrm{IL}} \mathrm{V}_{\mathrm{IL}}+\mathrm{M}_{\mathrm{aq}} \mathrm{V}_{\mathrm{aq}}} \times 100 \\
& \mathrm{~S}=\frac{\mathrm{M}_{\mathrm{st}} \mathrm{V}_{\mathrm{st}}}{\mathrm{M}_{\mathrm{st}} \mathrm{V}_{\mathrm{st}}+\mathrm{M}_{\mathrm{IL}} \mathrm{V}_{\mathrm{IL}}} \times 100
\end{aligned}
$$

where $\mathrm{M}\left(\mathrm{mg} \mathrm{L}^{-1}\right)$ is the concentration of the metal ion in the aqueous phase (aq), stripping phase (st) and the $\mathrm{IL}$, and V (L) is the volume of each respective phases. Each experiment and measurement were performed in triplicate and the error did not exceed $5 \%$.

\section{Results and Discussion}

\subsection{NMR spectroscopy of $\mathbf{P}_{\mathbf{8}, 8,8,12} \mathbf{R}_{2}$ POO}

The ${ }^{31} \mathrm{P}$ NMR spectra of $\mathrm{P}_{8,8,8,12} \mathrm{Cl}$ and $\mathrm{P}_{8,8,8,12} \mathrm{R}_{2} \mathrm{POO}$ both exhibited a singlet at around $34.5 \mathrm{ppm}$, as shown in Figure 2. This signal was attributed to the quaternary phosphorus atom of $\mathrm{P}_{8,8,8,12}[18,25]$. The ${ }^{31} \mathrm{P}$ NMR spectrum of $\mathrm{P}_{8,8,8,12} \mathrm{R}_{2} \mathrm{POO}$ also contained another peak at $33.6 \mathrm{ppm}$, as shown in Figure $2 \mathrm{~b}$, which could be associated with the quaternary phosphorus center atom of $\mathrm{R}_{2} \mathrm{POO}$ in the IL [18]. Impurity peaks were also seen in the ${ }^{31} \mathrm{P}$ NMR spectrum of $\mathrm{P}_{8,8,8,12} \mathrm{R}_{2} \mathrm{POO}$ at $46.41,46.20,37.99$, and $34.47 \mathrm{ppm}$. These peaks were ascribed to the presence of small amounts of phosphine isomer and various phosphine oxides in the bis(2,4,4-trimethylpenthyl)phosphinic acid. The ${ }^{31} \mathrm{P}$ NMR spectrum of $\mathrm{P}_{8,8,8,12} \mathrm{R}_{2} \mathrm{POO}$ showed a noticeable change after the extraction operation of the leachate: a new peak was observed at $47.4 \mathrm{ppm}$ (Figure 2c). This peak could be associated with the center atom of bis(2,4,4-trimethylpenthyl)phosphinic acid [23]. Moreover, there was a shift of the peak at $33.6 \mathrm{ppm}$ to $30.6 \mathrm{ppm}$ after the extraction process, whereas the peak at $34.5 \mathrm{ppm}$ was unaffected by the extraction process. bis(2,4,4-trimethylpenthyl)phosphinic acid was present after extraction because of the ion exchange process that occurred during the extraction process. As shown in the ${ }^{31} \mathrm{P} N M R$ spectrum of $\mathrm{P}_{8,8,8,12} \mathrm{R}_{2} \mathrm{POO}$ in Figure $2 \mathrm{~d}$, the content of bis(2,4,4-trimethylpenthyl)phosphinic acid, which is present at $47.4 \mathrm{ppm}$ decreased after 
adding excess $\mathrm{NaOH}$ and heating the solution to $55^{\circ} \mathrm{C}$. This indicates that the bis(2,4,4-trimethylpenthyl) phosphinic acid was converted back to $\mathrm{P}_{8,8,8,12} \mathrm{R}_{2} \mathrm{POO}$, which is similar to the synthesis process of $\mathrm{P}_{6,6,6,14} \mathrm{R}_{2} \mathrm{POO}[18,27]$.
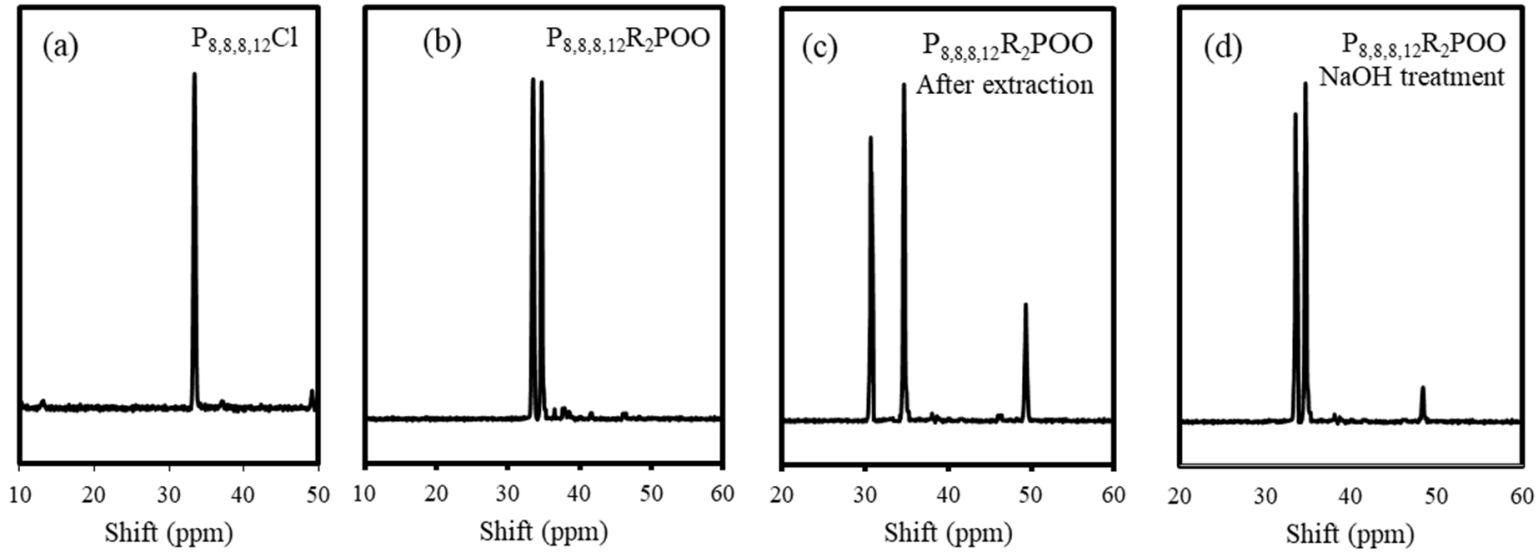

Figure 2. ${ }^{31} \mathrm{P}$ NMR spectra of (a) $\mathrm{P}_{8,8,8,12} \mathrm{Cl}$, (b) $\mathrm{P}_{8,8,8,12} \mathrm{R}_{2} \mathrm{POO}$, (c) $\mathrm{P}_{8,8,8,12} \mathrm{R}_{2} \mathrm{POO}$ after extraction, and (d) $\mathrm{P}_{8,8,8,12} \mathrm{R}_{2} \mathrm{POO}$ after $\mathrm{NaOH}$ treatment.

\subsection{Leaching of a spent LIB}
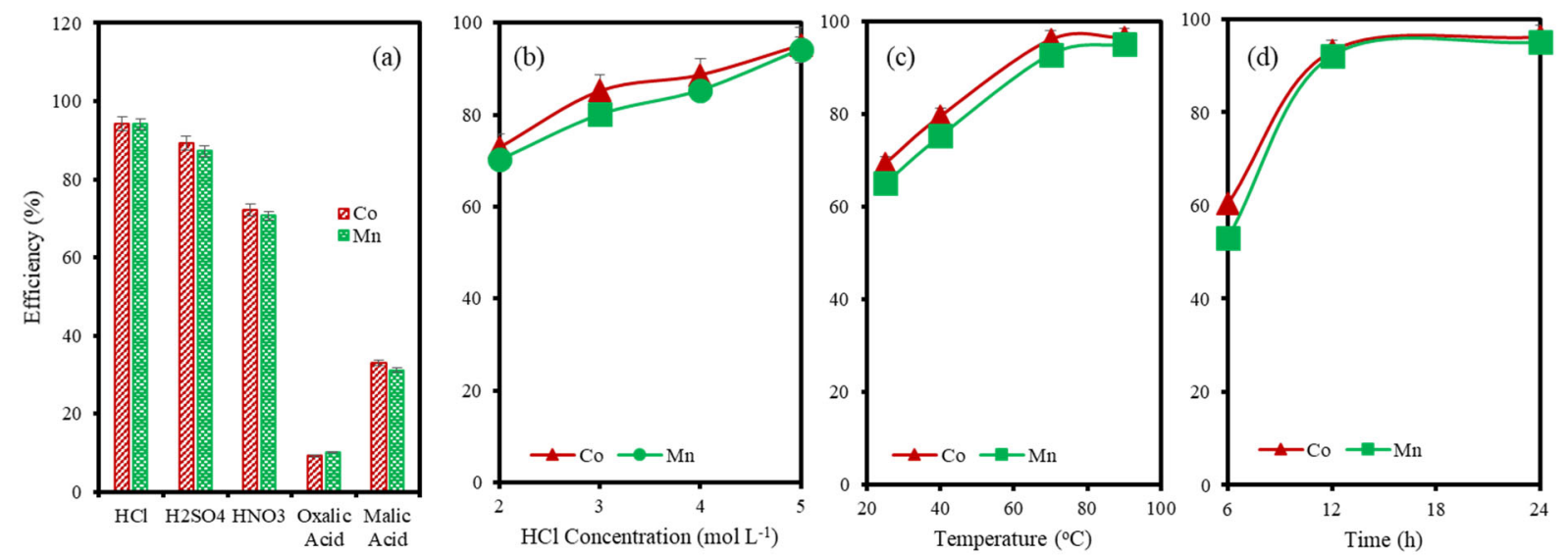

Figure 3. Factors influencing the dissolution efficiency of Co and Mn (2.5 g of spent LIB powder in $50 \mathrm{~mL}$ of $\mathrm{HCl}$ ). (a) Leaching solution (Leach solution $=5 \mathrm{~mol} \mathrm{~L}^{-1} \mathrm{HCl}, 5 \mathrm{~mol} \mathrm{~L}^{-1} \mathrm{H}_{2} \mathrm{SO}_{4}, 2 \mathrm{~mol} \mathrm{~L}^{-1} \mathrm{HNO}_{3}$, time $=$ $24 \mathrm{~h}$, temperature $=70^{\circ} \mathrm{C}$ ). (b) $\mathrm{HCl}$ concentration (time $=24 \mathrm{~h}$, temperature $=70^{\circ} \mathrm{C}$ ). (c) Leaching temperature (time $\left.=24 \mathrm{~h},[\mathrm{HCl}]_{\mathrm{aq}}=5 \mathrm{~mol} \mathrm{~L}^{-1}\right)$. (d) Leaching time $\left([\mathrm{HCl}]_{\mathrm{aq}}=5 \mathrm{~mol} \mathrm{~L}^{-1}\right.$, temperature $=$ $\left.70^{\circ} \mathrm{C}\right) . \mu \mathrm{XRF}$ of $5 \mathrm{~g}$ sample $(\%) \mathrm{Li}=3.7 ; \mathrm{Co}=11.9 ; \mathrm{Cu}=13.4 ; \mathrm{Ni}=1.1 ; \mathrm{Mn}=1.28 ; \mathrm{Al}=14.1 ; \mathrm{Fe}=1.8$.

Leaching from a spent LIB was carried out using several leaching solutions. The yields of Co and $\mathrm{Mn}$ to the mineral acids were over $80 \%$ in $5 \mathrm{~mol} \mathrm{~L}^{-1} \mathrm{HCl}$ and $5 \mathrm{~mol} \mathrm{~L}^{-1} \mathrm{H}_{2} \mathrm{SO}_{4}$ (Figure 3a). Meanwhile, 2 mol L ${ }^{-1} \mathrm{HNO}_{3}$ showed the lowest dissolution efficiency for both Co and Mn. Organic acids such as $1 \mathrm{~mol}$ $\mathrm{L}^{-1}$ oxalic acid and $1 \mathrm{~mol} \mathrm{~L}^{-1}$ malic acid were not effective as dissolution agents for $\mathrm{Co}$ and $\mathrm{Mn}$ from spent LIBs. Thus, subsequent investigation of Co and Mn dissolution from spent LIBs was done with $5 \mathrm{~mol} \mathrm{~L}^{-1}$ 
$\mathrm{HCl}$.

Then, the effect of $\mathrm{HCl}$ concentration was investigated on the dissolution of $\mathrm{Co}$ and $\mathrm{Mn}$. Co and $\mathrm{Mn}$ dissolution increased with $\mathrm{HCl}$ concentration (Figure 3b). However, considering that the leachate is subjected to an extraction procedure, it is not favorable for the $\mathrm{HCl}$ concentration of the feed solution to be too high. Thus, the subsequent experiment used $5 \mathrm{~mol} \mathrm{~L}^{-1} \mathrm{HCl}$ as the leaching solution. Leaching temperature and time were also investigated to further improve the dissolution efficiency of Co and $\mathrm{Mn}$. The dissolution of $\mathrm{Co}$ and $\mathrm{Mn}$ increased with leaching temperature (Figure 3c) up to $70^{\circ} \mathrm{C}$, where the highest dissolution efficiency for Co and Mn was observed. Further increasing the temperature above $70^{\circ} \mathrm{C}$ did not improve the dissolution efficiency. Increasing the leaching time from 6 to $12 \mathrm{~h}$ had a favorable effect on Co and Mn dissolution, whereas increasing the leaching time from 12 to $24 \mathrm{~h}$ only slightly improved the dissolution of $\mathrm{Co}$ and $\mathrm{Mn}$ (Figure 3d). Overall, the highest dissolution efficiency of Co and Mn was achieved using $5 \mathrm{~mol} \mathrm{~L}^{-1} \mathrm{HCl}$ for $12 \mathrm{~h}$ at $70^{\circ} \mathrm{C}$ (Table 1). The leachate also contained a considerable amount of $\mathrm{Ni}, \mathrm{Cu}$, and $\mathrm{Fe}$.

Table 1. Spent LIB leachate composition $\left(5 \mathrm{~g}\right.$ of sample per liter of $\left.5 \mathrm{~mol} \mathrm{~L}^{-1} \mathrm{HCl}\right)$.

\begin{tabular}{cccccccc} 
Metal & $\mathrm{Li}$ & $\mathrm{Co}$ & $\mathrm{Cu}$ & $\mathrm{Ni}$ & $\mathrm{Mn}$ & $\mathrm{Al}$ & $\mathrm{Fe}$ \\
\hline Leachate $\left(\mathrm{mg} \mathrm{L}^{-1}\right)$ & 111 & 560 & 38 & 41 & 58 & 2.7 & 48 \\
\hline
\end{tabular}

\subsection{Absorption spectral analysis}

The spectra of $[\mathrm{Co}(\mathrm{EDTA})]^{2-},[\mathrm{Ni}(\mathrm{EDTA})]^{2-}$ and $[\mathrm{Mn}(\mathrm{EDTA})]^{2-}$ complexes exhibited absorption peaks at 469,380 , and $448 \mathrm{~nm}$, respectively. In addition, the absorption spectra of $\mathrm{Cu}(\mathrm{II})$ and $\mathrm{Fe}(\mathrm{III})$ showed distinct peaks at 265 and $348 \mathrm{~nm}$, respectively. For $\mathrm{Cu}(\mathrm{II})$, the peak at $265 \mathrm{~nm}$ indicates the presence of $\mathrm{CuCl}_{2}$ in the solution [28,29]. The peak at $348 \mathrm{~nm}$ in the UV-vis spectrum of Fe(III) was attributed to the presence of $\mathrm{FeCl}_{3}$ in the solution [27]. The calibration curves of the metal complexes were linear in the designated concentration range. Furthermore, t-tests revealed that the intercepts of the calibration curves of all the metal complexes were close to zero. The linear range of Beer's law was observed at the designated wavelength for each complex.

\subsection{Extraction behavior}

Solutions of $\mathrm{Co}(\mathrm{II}), \mathrm{Mn}(\mathrm{II}), \mathrm{Ni}(\mathrm{II}), \mathrm{Fe}(\mathrm{III})$, and $\mathrm{Cu}(\mathrm{II})$ with a concentration of $100 \mathrm{mg} \mathrm{L}^{-1}$ were equilibrated with $\mathrm{P}_{8,8,8,12} \mathrm{R}_{2} \mathrm{POO}$ at different $\mathrm{HCl}$ concentrations and $\mathrm{V}_{\mathrm{aq}} / \mathrm{V}_{\mathrm{IL}}=2$. All metals except $\mathrm{Ni}(\mathrm{II})$ showed increased extraction efficiency with rising $\mathrm{HCl}$ concentration, as illustrated in Figure 4a. The highest extraction efficiencies of $\mathrm{Co}(\mathrm{II})$ and $\mathrm{Mn}$ (II) of $99 \%$ and $98 \%$, respectively, were achieved at an $\mathrm{HCl}$ concentration of $5 \mathrm{~mol} \mathrm{~L}^{-1}$. Moreover, $\mathrm{Fe}(\mathrm{III})$ and $\mathrm{Cu}(\mathrm{II})$ were also effectively extracted into the IL phase, achieving highest extraction efficiencies of $85 \%$ and $96 \%$, respectively. Figure $4 \mathrm{~b}$ shows the time course of the extraction process of the metals from the model leachate $\left([\mathrm{HCl}]=5 \mathrm{~mol} \mathrm{~L}^{-1}\right)$. The quantitative extractions of $\mathrm{Co}$ (II) and $\mathrm{Mn}$ (II) using $\mathrm{P}_{8,8,8,12} \mathrm{R}_{2} \mathrm{POO}$ were achieved within $3 \mathrm{~h}$. $\mathrm{Cu}$ (II) and $\mathrm{Fe}$ (II) were also extracted in considerable efficiency. Although Fe(III) required a longer operation time of $8 \mathrm{~h}$ to reach equilibrium. In contrast, $\mathrm{Ni}(\mathrm{II})$ was not extracted at any $\mathrm{HCl}$ concentration, even when the extraction period was prolonged. Thus, these results suggest that extraction for $3 \mathrm{~h}$ under the present experimental conditions allows the quantitative extraction of $\mathrm{Co}(\mathrm{II})$ and $\mathrm{Mn}$ (II) and suppresses the extraction of $\mathrm{Fe}(\mathrm{III})$. 

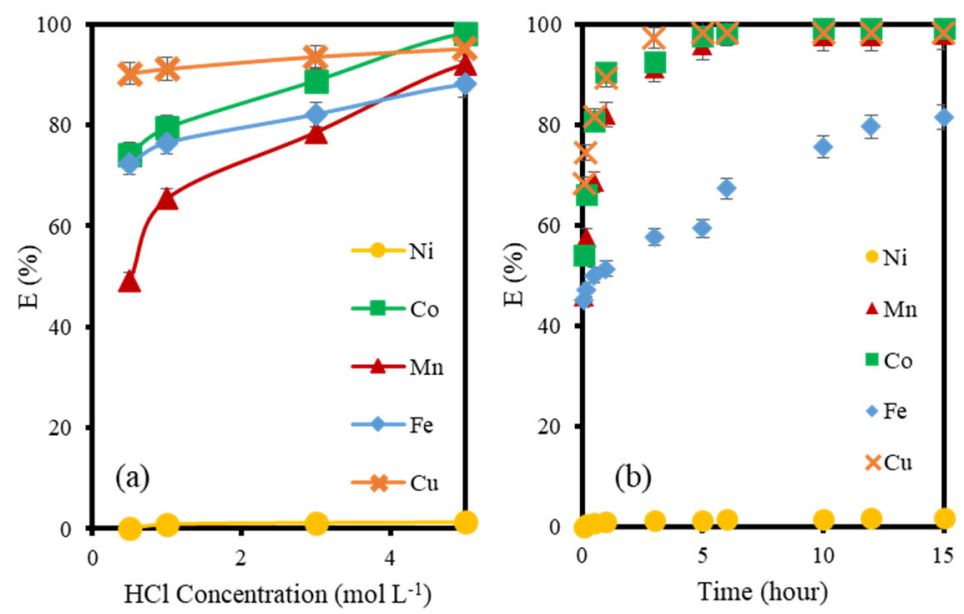

Figure 4. Extraction of metal complexes using $\mathrm{P}_{8,8,812} \mathrm{R}_{2} \mathrm{POO}$ with different (a) $\mathrm{HCl}$ concentrations ([metals $]_{\mathrm{aq}}=100 \mathrm{mg} \mathrm{L}^{-1},[\mathrm{HCl}]_{\mathrm{aq}}=5 \mathrm{~mol} \mathrm{~L}^{-1}, \mathrm{~V}_{\mathrm{aq}} / \mathrm{V}_{\mathrm{IL}}=2$, time: 12 hours) and (b) contact time ([metals $]_{\mathrm{aq}}$ $\left.=200 \mathrm{mg} \mathrm{L}^{-1},[\mathrm{HCl}]_{\mathrm{aq}}=5 \mathrm{~mol} \mathrm{~L}^{-1}, \mathrm{~V}_{\mathrm{aq}} / \mathrm{V}_{\mathrm{IL}}=4\right)$.
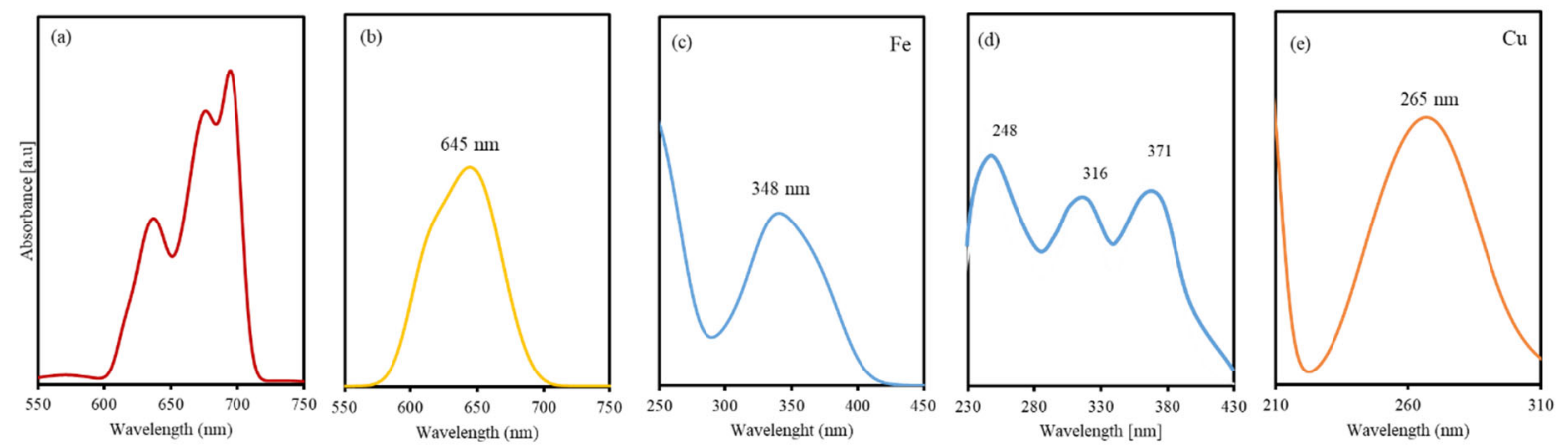

Figure 5. UV-vis spectra of (a) $\mathrm{Fe}(\mathrm{III}),(\mathrm{b}) \mathrm{Cu}(\mathrm{II})$, (c) $\mathrm{Co}(\mathrm{II})$ in IL phase. Solvent $=$ toluene, $[\mathrm{HCl}]_{\mathrm{aq}}=5 \mathrm{~mol}$ $\mathrm{L}^{-1}$. (d) $\mathrm{Co}(\mathrm{II})$ in IL phase. Solvent $=$ toluene, $[\mathrm{HCl}]_{\mathrm{aq}}=0 \mathrm{~mol} \mathrm{~L}^{-1}$ (e) $\mathrm{Fe}(\mathrm{III})$ in $\mathrm{P}_{8,8,8,12} \mathrm{R}_{2} \mathrm{POO}$ after extraction. $[\mathrm{HCl}]_{\mathrm{aq}}=5 \mathrm{~mol} \mathrm{~L}^{-1}$.

Different forms of $\mathrm{Co}(\mathrm{II})$ chlorocomplexes are present depending on the concentration of $\mathrm{HCl}$. According to several previous studies, $\mathrm{Co}(\mathrm{II})$ is present as $\left[\mathrm{CoCl}_{4}\right]^{2-}$ at high $\mathrm{HCl}$ concentration [28]. The extraction of $\mathrm{Co}$ (II) using $\mathrm{P}_{8,8,8,12} \mathrm{R}_{2} \mathrm{POO}$ has a different mechanism depending on the $\mathrm{HCl}$ concentration. In $5 \mathrm{~mol} \mathrm{~L}^{-1} \mathrm{HCl}$, the UV-vis spectrum of $\mathrm{Co}(\mathrm{II})$ loaded in $\mathrm{P}_{8,8,8,12} \mathrm{R}_{2} \mathrm{POO}$ showed a distinct peak within the range of $600-720 \mathrm{~nm}$ (Figure 5a), which corresponded to the presence of the tetrahedral $\mathrm{Co}$ (II) chlorocomplex [28]. Thus, the extraction process of $\mathrm{Co}(\mathrm{II})$ at such high $\mathrm{HCl}$ concentrations follows Eq. (3). $\mathrm{P}_{8,8,8,12} \mathrm{R}_{2} \mathrm{POO}$ also effectively extracted $\mathrm{Co}(\mathrm{II})$ without $\mathrm{HCl}$. This performance could be explained by the formation of coordination between $\mathrm{Co}$ (II) and bis(2,4,4-trimethylpentyl)phosphinate from the IL [29]. The IL phase after extraction showed an absorption peak at $645 \mathrm{~nm}$ (Figure 5b) that corresponded to the UV-vis spectrum of $\mathrm{Co}\left(\mathrm{R}_{2} \mathrm{POO}\right)_{2}$ [30]. This result indicates that anionic exchange occurs with $\mathrm{P}_{8,8,8,12} \mathrm{R}_{2} \mathrm{POO}$ to form $\mathrm{Co}\left(\mathrm{R}_{2} \mathrm{POO}\right)_{2}$ rather than ion association to form $\left(\mathrm{P}_{8,8,8,12}\right)_{2} \mathrm{CoCl}_{4}$, as shown in Eq. (3). Logarithmic plots of the distribution ratio of each metal and $\mathrm{P}_{8,8,8,12} \mathrm{R}_{2} \mathrm{POO}$ concentration were drawn to establish the 
ratio between the metal and ILs in the complexes formed during extraction. The slope of the plot for Co was approximately two, which indicated that the formation of extractable species required two molecules of $\mathrm{P}_{8,8,8,12} \mathrm{R}_{2} \mathrm{POO}$ per metal ion (Figure 6a). This result supports the Co(II) extraction mechanism described by Eq. (3)

$$
\begin{aligned}
& \mathrm{CoCl}_{4}{ }^{2-}+2 \mathrm{H}^{+}+2 \overline{\left(\mathrm{P}_{8,8,8,12}{ }^{+} \mathrm{R}_{2} \mathrm{POO}^{-}\right)} \rightleftharpoons \overline{\left(\mathrm{CoCl}_{4}{ }^{2-}\right)\left(\mathrm{P}_{8,8,8,12}{ }^{+}\right)_{2}}+2 \overline{\mathrm{HR}_{2} \mathrm{POO}} \\
& \mathrm{CoCl}_{2}+2 \overline{\mathrm{P}_{8,8,8,12}{ }^{+} \mathrm{R}_{2} \mathrm{POO}^{-}} \leftrightharpoons 2 \overline{\mathrm{P}_{8,8,8,12}{ }^{+} \mathrm{Cl}^{-}}+\overline{\mathrm{Co}\left(\mathrm{R}_{2} \mathrm{POO}\right)_{2}}
\end{aligned}
$$
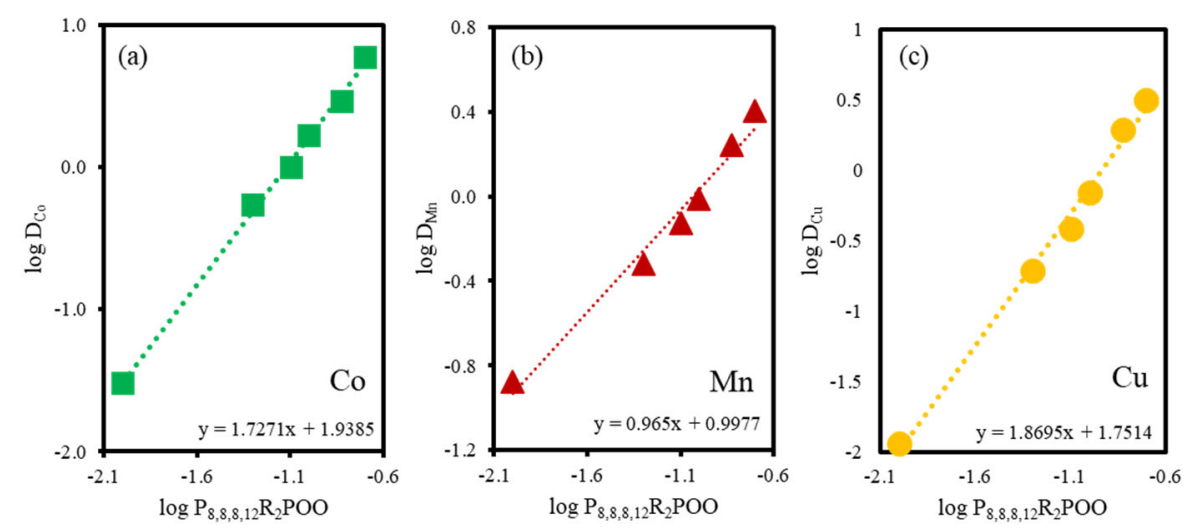

Figure 6. Effect of $\mathrm{P}_{8,8,8,12} \mathrm{R}_{2} \mathrm{POO}$ concentration on the extraction of (a) $\mathrm{Co}(\mathrm{II})$, (b) $\mathrm{Mn}$ (II), and (c) $\mathrm{Cu}(\mathrm{II})$. $[\text { metal }]_{\mathrm{aq}}=200 \mathrm{mg} \mathrm{L}{ }^{-1}, \mathrm{~V}_{\mathrm{aq}} / \mathrm{V}_{\mathrm{IL}}=4,\left[\mathrm{P}_{8,8,8,12} \mathrm{R}_{2} \mathrm{POO}\right]=0.01-0.1 \mathrm{~mol} \mathrm{~L}^{-1}$, solvent = toluene, $[\mathrm{HCl}]_{\mathrm{aq}}=5$ mol L ${ }^{-1}$.

In the chloride-based solution, chlorocomplexes of $\mathrm{Mn}(\mathrm{II})$ are formed such as $\mathrm{MnCl}, \mathrm{MnCl}_{2}$, and $\mathrm{MnCl}_{3}{ }^{-}$. Either anion exchange or an association reaction pathway may be involved in the extraction of $\mathrm{Mn}(\mathrm{II})$ by $\mathrm{P}_{8,8,8,12} \mathrm{R}_{2} \mathrm{POO}[12,34]$. Eqs (5) and (6) describe the anion exchange and association reactions of $\mathrm{Mn}(\mathrm{II})$ from the $\mathrm{HCl}$ solution by $\mathrm{P}_{8,8,8,12} \mathrm{R}_{2} \mathrm{POO}$, respectively.

$$
\begin{aligned}
& \mathrm{MnCl}_{3}{ }^{-}+\overline{\mathrm{P}_{8,8,8,12}{ }^{+} \mathrm{R}_{2} \mathrm{POO}^{-}}+\mathrm{H}^{+} \rightleftharpoons \overline{\left(\mathrm{MnCl}_{3}{ }^{-}\right)\left(\mathrm{P}_{8,8,8,12}{ }^{+}\right)}+\overline{\mathrm{HR}_{2} \mathrm{POO}} \\
& \mathrm{Mn}^{2+}+3 \mathrm{Cl}^{-}+\overline{\mathrm{P}_{8,8,8,12}{ }^{+} \mathrm{R}_{2} \mathrm{POO}^{-}}+\mathrm{H}^{+} \rightleftharpoons \overline{\left(\mathrm{MnCl}_{3}{ }^{-}\right)\left(\mathrm{R}_{3} \mathrm{R}^{\prime} \mathrm{P}^{+}\right)}+\overline{\mathrm{HR}_{2} \mathrm{POO}}
\end{aligned}
$$

The extraction efficiency of $\mathrm{Mn}(\mathrm{II})$ showed a positive trend along with the increase of $\mathrm{HCl}$ concentration. This corroborates with Eq. (6), which suggests a positive effect of chloride concentration on the extraction efficiency of $\mathrm{Mn}(\mathrm{II})$. While, in Eq. (5), the chloride concentration has little effect on the extraction efficiency of $\mathrm{Mn}(\mathrm{II})$. Therefore, Eq. (6) is plausible as the solvent extraction reaction of $\mathrm{Mn}(\mathrm{II})$ with $\mathrm{P}_{8,8,8,12} \mathrm{R}_{2} \mathrm{POO}$. The slope of logarithmic plots of IL concentration against the distribution ratio of $\mathrm{Mn}(\mathrm{II})$ was approximately one, indicating that the formation of extractable species required one molecule of $\mathrm{P}_{8,8,8,12} \mathrm{R}_{2} \mathrm{POO}$ per metal ion (Figure $6 \mathrm{~b}$ ).

According to UV-vis analysis, the presence of $\mathrm{FeCl}_{3}$ in the solution containing $\mathrm{Fe}(\mathrm{III})$ and $5 \mathrm{~mol} \mathrm{~L}^{-1}$ $\mathrm{HCl}$ was confirmed by the peak at $360 \mathrm{~nm}$ (Figure 5c) [32]. The extracted species were also determined through UV-vis spectrophotometry. The Fe(III)-loaded IL was diluted in acetone so that the Fe(III) concentration did not exceed the detection limit. The spectrum showed the typical peaks of $\left[\mathrm{FeCl}_{4}\right]^{-}$at 248 , 316, and $371 \mathrm{~nm}$ (Figure 5d) [27]. Thus, Fe(III) extraction could follow the ion association pathway as 
presented by Eq. (7).

$\mathrm{FeCl}_{3}+\overline{\left(\mathrm{P}_{8,8,8,12}{ }^{+} \mathrm{R}_{2} \mathrm{POO}^{-}\right)}+\mathrm{HCl} \rightleftharpoons \overline{\left(\mathrm{FeCl}_{4}{ }^{-}\right)\left(\mathrm{P}_{8,8,8,12}{ }^{+}\right)}+\overline{\mathrm{HR}_{2} \mathrm{POO}}$

As shown in Fig 5e, the absorption maximum at $268 \mathrm{~nm}$ indicates the presence of $\mathrm{CuCl}_{2}$ as the dominant chlorocomplex of $\mathrm{Cu}(\mathrm{II})$. In chloride medium with high $\mathrm{HCl}$ concentration, $\mathrm{CuCl}_{2}$ and $\left[\mathrm{CuCl}_{4}\right]^{-}$are stable chlorocomplexes of $\mathrm{Cu}$ (II) [36,37]. The slope of a logarithmic plot of the distribution ratio of $\mathrm{Cu}$ (II) against $\mathrm{P}_{8,8,8,12} \mathrm{R}_{2} \mathrm{POO}$ concentration after extraction was 2 (Figure 6c). Thus, the extraction pathway of $\mathrm{Cu}(\mathrm{II})$ probably proceeded by the ion association mechanism according to Eq. (8),

$\mathrm{CuCl}_{2}+\overline{2\left(\mathrm{P}_{8,8,8,12}{ }^{+} \mathrm{R}_{2} \mathrm{POO}^{-}\right)} \rightleftharpoons \overline{2 \mathrm{P}_{8,8,8,12}{ }^{+} \mathrm{Cl}^{-}}+\overline{\mathrm{Cu}\left(\mathrm{R}_{2} \mathrm{POO}\right)_{2}}$

\subsection{Stripping and scrubbing of metals from loaded ILs}

As described above, various metals aside from the target metals were extracted from the aqueous feed solution. Therefore, crucial factors on the recycling process of $\mathrm{Co}(\mathrm{II})$ and $\mathrm{Mn}$ (II) are found to be the ability to recover $\mathrm{Co}$ (II) and $\mathrm{Mn}(\mathrm{II})$, and removing most of co-extracted metal from the IL. The stripping of the metals from metal-loaded $\mathrm{P}_{8,8,8,12} \mathrm{R}_{2} \mathrm{POO}$ was then investigated using different stripping reagents. The results are listed in Table 2.

Table 2. Stripping of various metals from loaded $\mathrm{P}_{8,8,8,12} \mathrm{R}_{2} \mathrm{POO}$ using various stripping solutions.

\begin{tabular}{ccccc}
$\mathbf{S}(\mathbf{\%})$ & $\mathbf{C o}(\mathbf{I I})$ & $\mathbf{M n}(\mathbf{I I})$ & $\mathbf{F e}(\mathbf{I I I})$ & $\mathbf{C u ( I I )}$ \\
\hline $\mathrm{H}_{2} \mathrm{O}$ & $\mathbf{9 9 . 8}$ & 98.2 & 0 & 0 \\
$1 \mathrm{~mol} \mathrm{~L}^{-1} \mathrm{Na}_{2} \mathrm{~S}_{2} \mathrm{O}_{3}$ & 0 & $\mathbf{9 0 . 3}$ & $\mathbf{9 2 . 3}$ & 0 \\
$1 \mathrm{~mol} \mathrm{~L}^{-1} \mathrm{Na}_{2} \mathrm{SO}_{3}$ & 0 & 4.31 & $\mathbf{8 9 . 3}$ & 0 \\
$0.5 \mathrm{~mol} \mathrm{~L}^{-1} \mathrm{Na}_{2} \mathrm{SO}_{4}$ & 0 & $\mathbf{9 8 . 2}$ & 67.9 & 0 \\
$1 \mathrm{~mol} \mathrm{~L}^{-1} \mathrm{NH}_{4} \mathrm{NO}_{3}$ & 0.2 & $\mathbf{8 2 . 4}$ & 0.0 & 0 \\
$1 \mathrm{~mol} \mathrm{~L}^{-1} \mathrm{H}_{2} \mathrm{SO}_{4}$ & 72.1 & 57.7 & 11.0 & 91.5 \\
$5 \mathrm{~mol} \mathrm{~L}^{-1} \mathrm{H}_{2} \mathrm{SO}_{4}$ & 83.4 & 90.3 & 23.6 & $\mathbf{9 4 . 4}$ \\
\hline
\end{tabular}

As reported previously [35], 1 mol L ${ }^{-1} \mathrm{Na}_{2} \mathrm{SO}_{3}$ was able to effectively scrub $\mathrm{Fe}$ (III) from the loaded $\mathrm{P}_{8,8,8,12} \mathrm{R}_{2} \mathrm{POO}$. Our previous report also demonstrated that $\mathrm{Na}_{2} \mathrm{SO}_{3}$ was an efficient scrubbing agent to remove $\mathrm{Fe}$ (III) from the loaded $\mathrm{P}_{8,8,8,12} \mathrm{Cl}$ [36]. The superior performance of $\mathrm{Na}_{2} \mathrm{SO}_{3}$ can be attributed its ability to reduce $\mathrm{Fe}$ (III) to $\mathrm{Fe}$ (II) [35]. The reduction of $\mathrm{Fe}$ (III) to $\mathrm{Fe}$ (II) was analyzed by UV-vis spectroscopy of the scrubbing solution by the addition of 1,10-phenanthroline, in which resulted to a color transition towards translucent reddish. The presence of (phen) ${ }_{2} \mathrm{Fe}$ (II) complex was confirmed by a distinct peak at $517 \mathrm{~nm}$ in the UV-vis spectrum of the solution (Figure 7a) [37]. This further supported the scrubbing mechanism of $\mathrm{Fe}(\mathrm{III})$ with $\mathrm{Na}_{2} \mathrm{SO}_{3}$. 

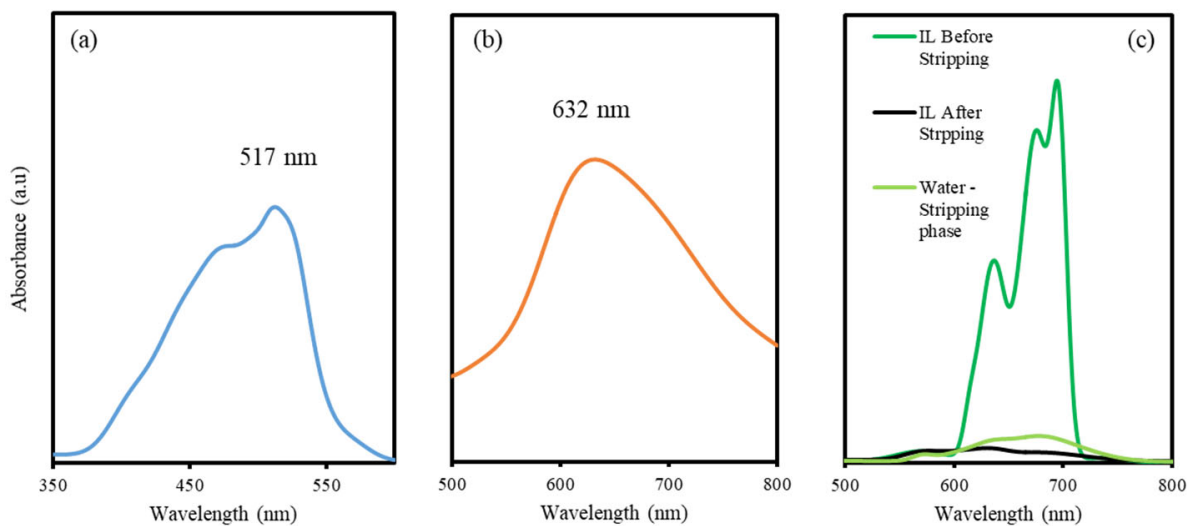

Figure 7. UV-vis spectra. (a) $\mathrm{Fe}(\mathrm{III})$. [stripping solution] $]_{\mathrm{aq}}=1 \mathrm{~mol} \mathrm{~L}^{-1} \mathrm{Na}_{2} \mathrm{SO}_{3}$, time $=30 \mathrm{~min}$, temperature $=50^{\circ} \mathrm{C},[1,10-$ phenanthroline $]=0.01 \mathrm{~mol} \mathrm{~L}^{-1}, \mathrm{~V}_{\mathrm{aq}} / \mathrm{V}_{\mathrm{IL}}=2$. (b) $\mathrm{Cu}(\mathrm{II})$. [stripping solution $]_{\mathrm{aq}}=5 \mathrm{~mol} \mathrm{~L}^{-1}$ $\mathrm{H}_{2} \mathrm{SO}_{4}, \mathrm{~V}_{\mathrm{aq}} / \mathrm{V}_{\mathrm{IL}}=2$. (c) $\mathrm{Co}(\mathrm{II})$. Stripping solution = water, $\mathrm{V}_{\mathrm{aq}} / \mathrm{V}_{\mathrm{IL}}=2$.

Efficient scrubbing of $\mathrm{Cu}(\mathrm{II})$ was achieved using $\mathrm{H}_{2} \mathrm{SO}_{4}$. The stripping was followed by the formation of $\mathrm{CuSO}_{4}$ in the stripping solution. An absorption maximum attributed to the presence of $\mathrm{CuSO}_{4}$ was observed at $632 \mathrm{~nm}$ from the UV-vis spectrum of the stripping solution (Figure 7b). Thus, stripping of $\mathrm{Cu}(\mathrm{II})$ probably occurs according to Eq. (10),

$\overline{\left[\mathrm{Cu}\left(\mathrm{R}_{2} \mathrm{POO}\right)_{2}\right.}+\mathrm{H}_{2} \mathrm{SO}_{4} \rightleftharpoons \mathrm{CuSO}_{4}+2 \overline{\mathrm{HR}_{2} \mathrm{POO}}$

In addition, $1 \mathrm{~mol} \mathrm{~L}^{-1} \mathrm{H}_{2} \mathrm{SO}_{4}$ was also able to effectively strip $\mathrm{Co}(\mathrm{II})$. To recover Co(II) from the stripping solution, $\mathrm{CuSO}_{4}$ can be precipitated with $\mathrm{CaCO}_{3}$ at elevated temperature [38]. Upon addition of $\mathrm{CaCO}_{3}$ to the solution, a light green precipitate formed. Thus, $\mathrm{Cu}(\mathrm{II})$ in the stripping solution was removed through precipitation using $\mathrm{CaCO}_{3}$ at a $\mathrm{pH}$ of 2.5 and temperature of $55^{\circ} \mathrm{C}$ for $2 \mathrm{~h}$, leaving $\mathrm{Co}$ (II) in the stripping solution. The precipitation reaction occurred as follows,

$2 \mathrm{CuSO}_{4}+2 \mathrm{CaCO}_{3(\mathrm{~s})}+3 \mathrm{H}_{2} \mathrm{O} \rightleftharpoons \mathrm{CuCO}_{3} \cdot \mathrm{Cu}(\mathrm{OH})_{2}+2 \mathrm{CaSO}_{4(\mathrm{~s})}+2 \mathrm{H}_{2} \mathrm{O}+\mathrm{CO}_{2}$

The recovery of $\mathrm{Co}$ (II) from the loaded $\mathrm{P}_{8,8,8,12} \mathrm{R}_{2} \mathrm{POO}$ is a crucial aspect of this study because $\mathrm{Co}$ (II) is an important target in the recycling process. Previous studies have shown that various stripping agents are effective to recover $\mathrm{Co}$ (II) from loaded ILs, such as water, $\mathrm{H}_{2} \mathrm{SO}_{4}$ and $\mathrm{NH}_{3}[9-11,42]$. Therefore, water, $\mathrm{H}_{2} \mathrm{SO}_{4}$ and $\mathrm{NH}_{3}$ were tested as stripping agents for extracted $\mathrm{Co}$ (II) in the loaded IL phase, which was obtained after extraction from an aqueous leaching solution containing Co(II). As seen in Table 2, all stripping agents effectively recovered Co(II) from the loaded IL. Water was able to recover Co(II) quantitatively from the loaded IL as well as Mn(II). The effective stripping of Co(II) by water was possible because water washed the excess chloride from the IL phase, leading to the transformation of $\left[\mathrm{CoCl}_{4}\right]^{2-}$ to $\left[\mathrm{Co}\left(\mathrm{H}_{2} \mathrm{O}\right)_{6}\right]^{2+}$. While $\left[\mathrm{CoCl}_{4}\right]^{2-}$ was observed in the IL phase before the stripping process, it was not detected in the water after the stripping process (Figure 7c). This is because the equilibrium between these two Co(II) complexes is easily shifted [40], following Eq. (11).

$\left.\overline{\left(\mathrm{CoCl}_{4}{ }^{2-}\right)\left(\mathrm{P}_{8,8,8,12}{ }^{+}\right)_{2}}+6 \mathrm{H}_{2} \mathrm{O} \rightleftharpoons \mathrm{Co}\left(\mathrm{H}_{2} \mathrm{O}\right)_{6}{ }^{2+}+2 \overline{\left(\mathrm{P}_{8,8,8,12}{ }^{+} \mathrm{Cl}^{-}\right.}\right)+2 \mathrm{Cl}^{-}$

Various types of stripping agents, including reductive $\left(\mathrm{Na}_{2} \mathrm{SO}_{3}\right.$ and $\left.\mathrm{Na}_{2} \mathrm{~S}_{2} \mathrm{O}_{3}\right)$ or oxidative $\left(\mathrm{NH}_{4} \mathrm{NO}_{3}\right.$ 
and $\mathrm{HNO}_{3}$ ) agents, were investigated to remove $\mathrm{Mn}(\mathrm{II})$ from the loaded IL, as shown in Table 2. Since $\mathrm{Mn}$ (II) can either be oxidized or reduced, both oxidants and reductants were effective as the stripping agent for $\mathrm{Mn}(\mathrm{II})$ from $\mathrm{P}_{8,8,8,12} \mathrm{R}_{2} \mathrm{POO}$. However, a white precipitate was formed at the interface between the IL and $\mathrm{NH}_{4} \mathrm{NO}_{3}$ solution, which hindered the separation of the phases and limited the IL reusability. The lower stripping percentage of $\mathrm{Mn}(\mathrm{II})$ using $\mathrm{Na}_{2} \mathrm{SO}_{3}$ compared to the case for $\mathrm{Na}_{2} \mathrm{~S}_{2} \mathrm{O}_{3}$ probably is caused by its lower reduction potential. Stripping of $\mathrm{Mn}$ (II) using $\mathrm{Na}_{2} \mathrm{~S}_{2} \mathrm{O}_{3}$ also resulted in the stripping of $\mathrm{Fe}(\mathrm{III})$ because of the reduction of $\mathrm{Fe}(\mathrm{III})$ to $\mathrm{Fe}(\mathrm{II})$. Moreover, stripping of $\mathrm{Mn}$ (II) from $\mathrm{P}_{8,8,8,12} \mathrm{R}_{2} \mathrm{POO}$ was also effectively achieved by water and $\mathrm{Na}_{2} \mathrm{SO}_{4}$. Thus, water was able to effectively recover both $\mathrm{Co}$ (II) and $\mathrm{Mn}$ (II) from the IL. Low stability of $\left[\mathrm{MnCl}_{3}\right]^{-}$was largely influenced the capability of $\mathrm{Na}_{2} \mathrm{SO}_{4}$ to recover $\mathrm{Mn}$ (II) from loaded IL. Thus, $0.5 \mathrm{~mol} \mathrm{~L}^{-1} \mathrm{Na}_{2} \mathrm{SO}_{4}$ was chosen as a suitable stripping solution to recover $\mathrm{Mn}$ (II) from loaded $\mathrm{P}_{8,8,8,12} \mathrm{R}_{2} \mathrm{POO}$.

$\overline{\left(\mathrm{MnCl}_{3}{ }^{-}\right)\left(\mathrm{P}_{8,8,8,12}{ }^{+}\right.}+\mathrm{Na}_{2} \mathrm{SO}_{4} \rightarrow 2 \overline{\left(\mathrm{P}_{8,8,8,12}{ }^{+} \mathrm{Cl}^{-}\right)}+\mathrm{MnSO}_{4}+2 \mathrm{NaCl}+2 \mathrm{Cl}^{-}$

\subsection{Recovery of Co(II) and Mn(II) from spent LIB leachate}

A solution of metals leached from a spent LIB was analyzed using AAS. A recovery process for $\mathrm{Co}(\mathrm{II})$ and $\mathrm{Mn}$ (II) from the spent LIB leachate was developed according to the results obtained using the single metal solutions, as summarized in Scheme 1. Figure 8 presents the metal concentrations in the solution after each process. Initially, extraction of $\mathrm{Co}(\mathrm{II})$ and $\mathrm{Mn}$ (II) was carried out by mixing the leachate with $\mathrm{P}_{8,8,8,12} \mathrm{R}_{2} \mathrm{POO}$. $\mathrm{Co}$ (II) and $\mathrm{Mn}$ (II) were almost quantitatively extracted, followed by $\mathrm{Cu}$ (II) (approximately 90\%), and then Fe(III) (approximately 52\%), as shown in Figure 8a.

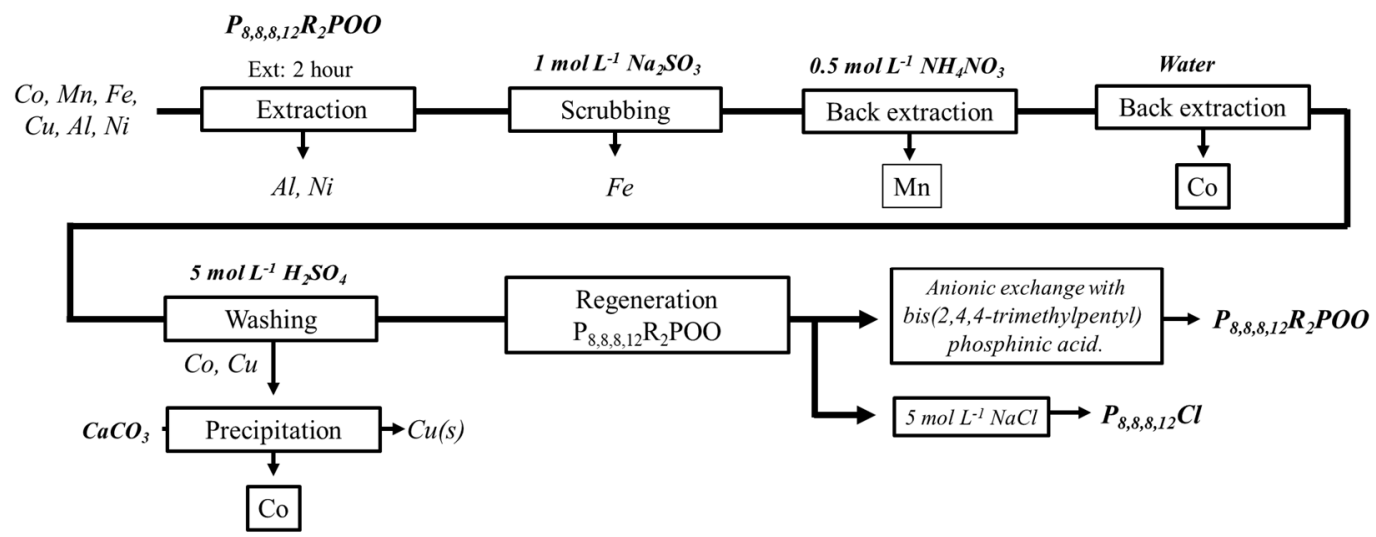

Scheme 1. Flow chart summarizing the separation and recovery process of $\mathrm{Co}(\mathrm{II})$ and $\mathrm{Mn}$ (II) from a spent LIB leachate. $\mathrm{V}_{\mathrm{aq}} / \mathrm{V}_{\mathrm{IL}}=2,[\mathrm{HCl}]_{\mathrm{aq}}=5 \mathrm{~mol} \mathrm{~L}^{-1}$. 

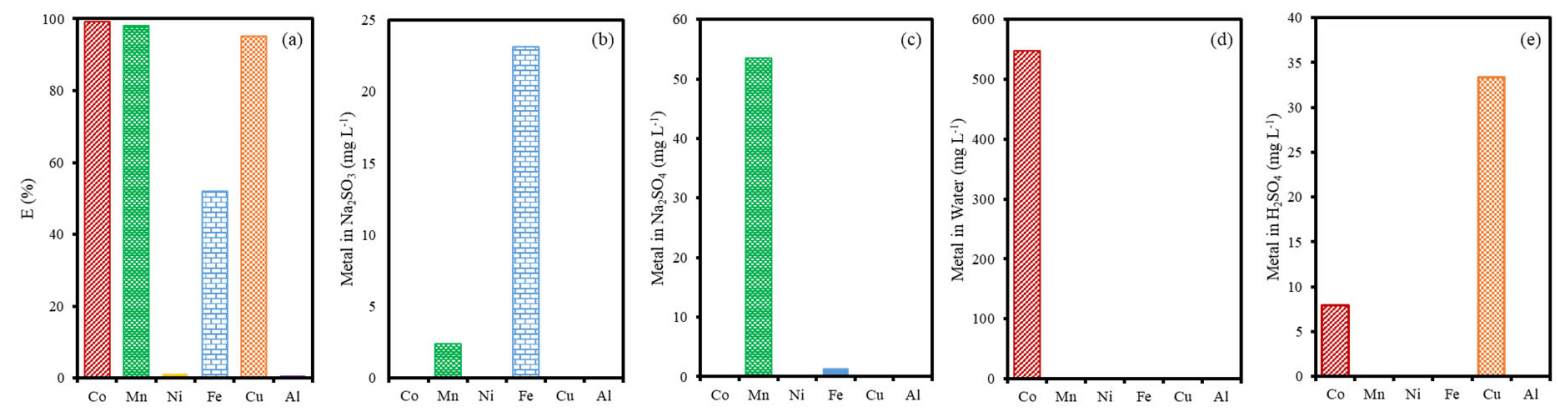

Figure 8. Analysis of the extraction process of spent LIB leachate, $\mathrm{V}_{\mathrm{aq}} / \mathrm{V}_{\mathrm{IL}}=2$. (a) Initial extraction process. $[\mathrm{HCl}]_{\mathrm{aq}}=5 \mathrm{~mol} \mathrm{~L}^{-1}$, time $=3 \mathrm{~h}$. (b) $\mathrm{Fe}(\mathrm{III})$ scrubbing. $\left[\mathrm{Na}_{2} \mathrm{SO}_{3}\right]=1.0 \mathrm{~mol} \mathrm{~L}^{-1}$, temperature $=30^{\circ} \mathrm{C}$, time $=$ 30 min. (c) $\mathrm{Mn}$ (II) stripping. $\left[\mathrm{Na}_{2} \mathrm{SO}_{4}\right]=0.5 \mathrm{~mol} \mathrm{~L}^{-1}$. (d) $\mathrm{Co}$ (II) stripping. Stripping solution = water. (e) $\mathrm{Cu}(\mathrm{II})$ washing. $\left[\mathrm{H}_{2} \mathrm{SO}_{4}\right]=1 \mathrm{~mol} \mathrm{~L}^{-1}$.

Then, the metal-loaded IL was subjected to scrubbing with $1 \mathrm{ml} \mathrm{L}^{-1} \mathrm{Na}_{2} \mathrm{SO}_{3}$ for $30 \mathrm{~min}$ at $30^{\circ} \mathrm{C}$, in which was able to almost completely removed Fe(III) from the loaded IL, while leaving $\mathrm{Co}(\mathrm{II}), \mathrm{Mn}$ (II), and $\mathrm{Cu}(\mathrm{II})$ in the IL (Figure $8 \mathrm{~b}$ ). Then, recovery of $\mathrm{Mn}$ (II) from the IL was done by using $0.5 \mathrm{~mol} \mathrm{~L}^{-1} \mathrm{Na}_{2} \mathrm{SO}_{4}$ (Figure 8c). However, this was also accompanied by the stripping of a considerable quantity of $\mathrm{Fe}(\mathrm{III})$. Then, the stripping solution containing $\mathrm{Mn}$ (II) was purified from $\mathrm{Fe}(\mathrm{II})$ through precipitation using $\mathrm{CaCO}_{3}$ at $\mathrm{pH} 2.5$ and $85^{\circ} \mathrm{C}$ for $2 \mathrm{~h}$, which achieved almost quantitative removal of $\mathrm{Fe}$ (II) from the stripping solution containing $\mathrm{Mn}(\mathrm{II})$. Co(II) recovery was then conducted with water. $\mathrm{Co}(\mathrm{II})$ was efficiently recovered and because a small amount of $\mathrm{Mn}$ (II) remained in the IL, the purity of $\mathrm{Co}$ (II) in the stripping solution was high (98\%) (Figure 8d). Lastly, $\mathrm{Cu}$ (II) was washed from the loaded IL with $1 \mathrm{~mol} \mathrm{~L}^{-1} \mathrm{H}_{2} \mathrm{SO}_{4}$, which achieved almost quantitative removal of $\mathrm{Cu}(\mathrm{II})$ (Figure 8e). However, a substantial amount of residual $\mathrm{Co}(\mathrm{II})$ was also stripped with $\mathrm{H}_{2} \mathrm{SO}_{4}$. Thus, $\mathrm{Cu}$ (II) in the stripping solution was then subjected to precipitation with $\mathrm{CaCO}_{3}$, which left $\mathrm{Co}$ (II) in the stripping phase $\left(1 \mathrm{~mol} \mathrm{~L}^{-1} \mathrm{H}_{2} \mathrm{SO}_{4}\right)$.

\section{Conclusion}

The novel IL $\mathrm{P}_{8,8,8,12} \mathrm{R} 2 \mathrm{POO}$ was synthesized with a purity of $98 \%$. This hydrophobic IL was found to be an effective extractant for $\mathrm{Co}(\mathrm{II})$ and $\mathrm{Mn}$ (II) from chloride medium. $\mathrm{P}_{8,8,8,12} \mathrm{R} 2 \mathrm{POO}$ effectively extracted $\mathrm{Co}(\mathrm{II})$ and $\mathrm{Mn}$ (II) at high levels of $99 \%$ and $98 \%$, respectively, regardless of the $\mathrm{HCl}$ concentration of the medium. The metal extraction to the IL phase proceeded through an anion-exchange mechanism. In the presence of other metals, $\mathrm{P}_{8,8,8,12} \mathrm{R}_{2} \mathrm{POO}$ also extracted substantial amounts of $\mathrm{Fe}(\mathrm{III})$ and $\mathrm{Cu}(\mathrm{II})$. Effective separation of $\mathrm{Co}(\mathrm{II})$ and $\mathrm{Mn}$ (II) and the removal of impurities such as $\mathrm{Fe}(\mathrm{III})$ and $\mathrm{Cu}$ (II) were achieved by scrubbing, washing, and precipitation steps. $\mathrm{P}_{8,8,8,12} \mathrm{R}_{2} \mathrm{POO}$ shows potential for use as an extraction solvent for $\mathrm{Co}$ (II) and $\mathrm{Mn}$ (II) from spent LIBs. Our results illustrate that the performance of ILs for target metals can be readily tuned by changing their molecular structure.

\section{Acknowledgement}

This work was supported by the Environment Research and Technology Development Fund (ERTDF, 
No. 3-2004) of the Ministry of the Environment, Japan; SUZUKI Foundation(R1-No.28) and Universitas Airlangga under grant Hibah Riset Mandat 2020. We thank Natasha Lundin, PhD, from Edanz Group (www.edanzediting.com/ac) for editing a draft of this manuscript.

\section{References}

1) S. Castillo, F. Ansart, C. Laberty-Robert, J. Portal, J. Power Sources, 112, 247-254 (2002).

2) B. Scrosati, J. Garche, J. Power Sources, 195, 2419-2430 (2010).

3) A. Chagnes, B. Pospiech, J. Chem. Technol. Biotechnol., 88, 1191-1199 (2013).

4) T. Georgi-Maschler, B. Friedrich, R. Weyhe, H. Heegn, M. Rutz, J. Power Sources, 207, 173-182 (2012).

5) N. B. Devi, K. C. Nathsarma, V. Chakravortty, Hydrometallurgy, 49, 47-61 (1998).

6) I. Y. Fleitlikh, G. L. Pashkov, N. A. Grigorieva, L. K. Nikiforova, M. A. Pleshkov, Y. M. Shneerson, Solvent Extr. Ion Exch., 29, $782-799$ (2011).

7) L. Luo, J. H. Wei, G. Y. Wu, F. Toyohisa, S. Atsushi, Trans. Nonferrous Met. Soc. China (English ed.), 16, 687-692 (2006).

8) P. Rybka, M. Regel-Rosocka, Sep. Sci. Technol., 47, 1296-1302 (2012).

9) S. Wellens, B. Thijs, K. Binnemans, Green Chem., 14, 1657-1665 (2012).

10) D. E. Chaverra, O. J. Restrepo-Baena, M. C. Ruiz, ACS Omega, 5, 5643-5650 (2020).

11) P. D. Ola, Y. Kurobe, M. Matsumoto, Chem. Eng. Trans., 57, 1135-1140 (2017).

12) P. D. Ola, M. Matsumoto, K. Kondo, Desalin. Water Treat., 75, 325-330 (2017).

13) S. Wellens, B. Thijs, C. Möller, K. Binnemans, Phys. Chem. Chem. Phys., 15, 9663-9669 (2013).

14) R. Torkaman, M. Asadollahzadeh, M. Torab-Mostaedi, M. G. Maragheh, Sep. Purif. Technol., 186, 318-325 (2017).

15) C. J. Bradaric, A. Downard, C. Kennedy, A. J. Robertson, Y. Zhou, Green Chem., 5, 143-152 (2003).

16) A. T. N. Fajar, F. Kubota, M. L. Firmansyah, M. Goto, Ind. Eng. Chem. Res., 58, 22334-22342 (2019).

17) M. L. Firmansyah, A. T. N. Fajar, W. Yoshida, T. Hanada, M. Goto, J. Chem. Eng. Jpn., 53, 1-8 (2020).

18) S. A. Dharaskar, K. L. Wasewar, M. N. Varma, D. Z. Shende, K. K. Tadi, C. K. Yoo, Fuel Process. Technol., 123, 1-10 (2014).

19) N. Liu, R. A. Senthil, Y. Man, J. Pan, X. Jin, Y. Sun, X. Liu, Int. J. Electrochem. Sci., 13, 11568-11579 (2018).

20) C. M. Mirea, I. Diaconu, E. A. Şerban, E. Ruse, UPB Sci. Bull., Ser. B, 77, 103-114 (2015).

21) M. L. Firmansyah, F. Kubota, W. Yoshida, M. Goto, Ind. Eng. Chem. Res., 58, 3845-3852 (2019).

22) G. Adamová, R. L. Gardas, L. P. N. Rebelo, A. J. Robertson, K. R. Seddon, Dalton Trans., 40, 12750-12764 (2011).

23) D. Cholico-Gonzalez, A. Chagnes, G. Cote, M. Avila-Rodriguez, J. Mol. Liq., 209, 203-208 (2015).

24) J. Sun, P. C. Howlett, D. R. MacFarlane, J. Lin, M. Forsyth, Electrochim. Acta, 54, 254-260 (2008).

25) S. W. Ju, N. Zhang, Z. Q. Wang, R. T. Zhang, D. W. Zeng, X. P. Shao, K. Lin, Chin. J. Chem. Phys., 30, 657-663 (2017).

26) H. R. Ong, M. M. R. Khan, R. Ramli, Y. Du, S. Xi, R. M. Yunus, RSC Adv., 5, 24544-24549 (2015). 
27) L. Cui, Z. Zhao, Y. Guo, F. Cheng, Sep. Purif. Technol., 199, 304-310 (2018).

28) F. A. Cotton, D. M. L. Goodgame, M. Goodgame, J. Am. Chem. Soc., 83, 4690-4699 (1961).

29) I. Van de Voorde, L. Pinoy, E. Courtijn, F. Verpoort, Solvent Extr. Ion Exch., 24, 893-914 (2006).

30) N. B. Devi, K. C. Nathsarma, V. Chakravortty, Hydrometallurgy, 34, 331-342 (1994).

31) M. S. Lee, M. Filiz, Mater. Trans., 49, 2642-2647 (2008).

32) L. Cui, F. Cheng, J. Zhou, Ind. Eng. Chem. Res., 54, 7534-7542 (2015).

33) B. Pospiech, J. Solution Chem., 44, 2431-2447 (2015).

34) B. Pospiech, Hydrometallurgy, 154, 88-94 (2015).

35) K. Xiang, H. Liu, B. Yang, C. Zhang, S. Yang, Z. Liu, C. Liu, X. Xie, L. Chai, X. Min, Environ. Sci. Pollut. Res., 23, 8113-8119 (2016).

36) M. L. Firmansyah, F. Kubota, W. Yoshida, M. Goto, Ind. Eng. Chem. Res., 58, 3845-3852 (2019).

37) C. Vakh, E. Freze, A. Pochivalov, E. Evdokimova, M. Kamencev, L. Moskvin, A. Bulatov, J. Pharmacol. Toxicol. Methods, 73, 56-62 (2015).

38) X. Li, Z. Lei, J. Qu, Z. Li, Q. Zhang, Sep. Sci. Technol., 51, 2772-2779 (2016).

39) B. Onghena, S. Valgaeren, T. Vander Hoogerstraete, K. Binnemans, RSC Adv., 7, 35992-35999 (2017).

40) N. M. Barrera, J. L. McCarty, V. Dragojlovic, Chem. Educ., 7, 142-145 (2002). 